\title{
Correction to: Introducing the Symposium on Mobilizing Interest Groups in America
}

\author{
Andrew S. McFarland ${ }^{1}$
}

Published online: 24 June 2021

(c) Springer Nature Limited 2021

\section{Correction to: Interest Groups \& Advocacy (2021) 10:68-71 https://doi.org/10.1057/s41309-021-00117-0}

The article Introducing the Symposium on Mobilizing Interest Groups in America, written by Andrew S. McFarland, was originally published online on the publisher's internet portal on 20 February 2021 with Open Access under a under a Creative Commons Attribution 4.0 International License, which permits use, sharing, adaptation, distribution and reproduction in any medium or format, as long as you give appropriate credit to the original author(s) and the source, provide a link to the Creative Commons licence, and indicate if changes were made. The images or other third party material in this article are included in the article's Creative Commons licence, unless indicated otherwise in a credit line to the material. If material is not included in the article's Creative Commons licence and your intended use is not permitted by statutory regulation or exceeds the permitted use, you will need to obtain permission directly from the copyright holder. To view a copy of this licence, visit http://creat ivecommons.org/licenses/by/4.0/.

With the author's/authors' decision to cancel Open Access the copyright of the article changed on 8 June 2021 to (C) Springer Nature Limited 2021 with all rights reserved.

The original article has been corrected.

Publisher's Note Springer Nature remains neutral with regard to jurisdictional claims in published maps and institutional affiliations.

The original article can be found online at https://doi.org/10.1057/s41309-021-00117-0.

Andrew S. McFarland

amcfarla@uic.edu

1 Political Science Department, University of Illinois At Chicago, Chicago, IL 60607, USA 